\title{
Analysis of meiotic behavior in Cordia ecalyculata Vell. (Boraginaceae)
}

\author{
Damião do Nascimento ${ }^{1}$ \\ Patricia Gonçalves Sbais ${ }^{2}$ \\ Andréia Rodrigues Alonso-Pereira ${ }^{1}$ \\ Adriele Fialho do Canto ${ }^{1}$ \\ Mariza Barion Romagnolo ${ }^{2}$ \\ Odair Alberton ${ }^{1}$ \\ Claudicéia Risso-Pascotto ${ }^{3 *}$

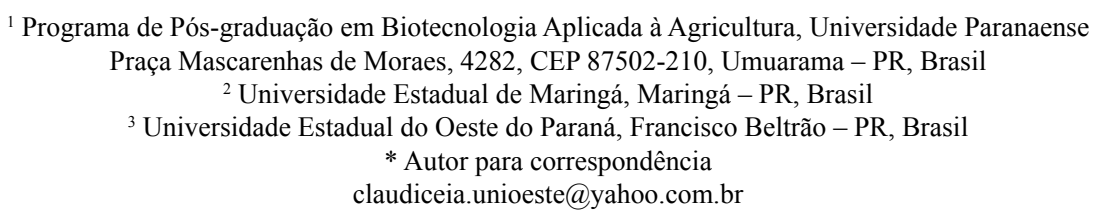

Submetido em 20/03/2014

Aceito para publicação em 01/07/2014

\section{Resumo}

Análise do comportamento meiótico em Cordia ecalyculata Vell. (Boraginaceae). A espécie Cordia ecalyculata pertence à família Boraginaceae, é conhecida popularmente por café de bugre. Para fins medicinais é indicada como tônico, diurético, anti-inflamatório e inibidor do apetite. Visando contribuir para um melhor entendimento da espécie, inflorescências jovens de seis indivíduos foram coletadas e fixadas em solução de etanol e ácido acético (3:1) por $24 \mathrm{~h}$. As lâminas foram preparadas utilizando a técnica de esmagamento e coradas com carmim acético a 1\%. Durante a microsporogênese poucas irregularidades foram encontradas, as mais frequentes estão relacionadas à segregação irregular dos cromossomos, tais como: Ascensão precoce para os polos em metáfase I e II, bivalente não orientado em metáfase I e II, e cromossomos retardatários em anáfase I e II, levando a formação de micronúcleos. Outra irregularidade observada esta relacionada a organização das fibras dos fusos em meiose II, que se organizam na forma em $\mathrm{T}$ e V. Na configuração de fuso na forma de $\mathrm{V}$ ocorreu fusão entre dois núcleos que estavam próximos, formando tríade ao invés de tétrade, levando à formação de micrósporos $2 \mathrm{n}$ final da meiose. Entretanto, as irregularidades observadas não comprometeram a fertilidade da espécie em análise, uma vez que a viabilidade dos grãos de pólen variou de $95,42 \%$ a $100 \%$.

Palavras-chave: Cordia ecalycula; Fuso irregular; Meiose; Microsporogênese

\section{Abstract}

Cordia ecalyculata belongs to the Boraginaceae family, and is commonly known as buggy coffee. It is indicated for medicinal use as a tonic, diuretic, anti-inflammatory and appetite suppressant. Young inflorescences of 
six individuals were collected and fixed in a mixture of ethanol and acetic acid (3:1) for 24 hours. The slides were prepared by crushing and staining tissue with $1 \%$ acetic carmine. During microsporogenesis some irregularities were observed, mostly frequently related to irregular chromosome segregation. Irregularities included: precocious migration to poles in metaphase I and II, disoriented bivalent chromosomes at metaphase I and II, laggard chromosomes in anaphase I and II, and micronuclei formation. We also observed irregular spindle organization in meiosis II, leading to ' $\mathrm{T}$ ' and ' $\mathrm{V}$ ' shaped spindle configurations. In the V-shaped configuration, two nearby nuclei fused, forming triads instead of tetrads; this lead to formation of $2 \mathrm{n}$ microspore at the end of meiosis. However, pollen grain viability was not compromised, as pollen grain viability varied between $95.42 \%$ and $100 \%$.

Key words: Cordia ecalycula; Irregular spindle; Meiosis; Microsporogenesis

\section{Introduction}

Cordia ecalyculata Vell, known commonly as buggy coffee, is an arboreal, evergreen, heliophytic species typical of humid and fertile soils in semideciduous forests (SOUZA; LORENZI, 2005). The wood can be used to make light boxes, matchsticks and toys, and is suitable for street afforestation. This species produces red fruit, similar to coffee. The fruits are appreciated by animals, and can be toasted and commercialized as a tea product (CRUZ, 1995; LORENZI, 2002). Cordia ecalyculata is also widely used for medicinal purposes, primarily by indigenous people, being indicated as a tonic, diuretic, anti-inflammatory agent and appetite inhibitor (LORENZI; MATOS, 2008).

Cytogenetics is a field focused on the study of cytological events, mainly those related to the behavior and genetics of chromosomes. Meiosis and mitosis are the basic events studied by cytogeneticists (MONDIN; NETO, 2006). During the meiotic process, changes may occur in various stages that can ultimately lead to formation of structural anomalies which compromise gamete viability (AULER et al., 2006). Despite the high diversity of native arboreal species in Brazil, little is known about the cytogenetic behavior of some of these species. Cytological reviews can enhance the efficiency of current conservation strategies, while improving the greater body of research regarding these species (AULER et al., 2006; SOUZA-KANESHIMA et al., 2010; KIIHL et al., 2011; GODOY et al., 2012).

The aim of this work was to study the meiotic behavior of Cordia ecalyculata Vell using the microsporogenesis technique to estimate the viability of the pollen grains, and to thereby obtain information that may assist in the maintenance and conservation of the species.

\section{Material and Methods}

Six individuals (Cordia ecalyculata Vell) were collected in Caiuá Ecological Station in Diamante do Norte, Paraná State, Brazil (22 ${ }^{\circ} 41^{\prime} \mathrm{S}$ and $\left.52^{\circ} 55^{\prime} \mathrm{W}\right)$ for analysis of young inflorescences. To identify the species of the individuals, herbarium specimens were mounted according to standard techniques (FIDALGO; BONONI, 1989), and were deposited in the State University of Maringá - UEM herbarium, under the following registration numbers: HUEM 16283, HUEM 16417, HUEM 21970, HUEM 23888, HUEM 23897 and HUEM 25385.

Inflorescences in different stages of development were collected and fixed in a solution of ethanol and glacial acetic acid (3:1) for a period of $24 \mathrm{~h}$ at room temperature, after which they were washed in $70 \%$ ethanol and stored in $70 \%$ ethanol at $4{ }^{\circ} \mathrm{C}$ until use. Microscope slides were prepared by crushing and staining it with $1 \%$ acetic carmine. For analysis of meiotic behavior, at least 1000 cells from each individual were analyzed in various meiotic phases. The staining intensity and size of approximately 300 microspores and pollen grains of each individual were analyzed and classified following the criteria described by CaetanoPereira et al. (1999) in order to estimate pollen grain viability.

Analyses were performed via optical microscopy, and the cells were photographed using a digital camera (Celestron, Model 44420), changing only contrast and brightness between sample visualization. 


\section{Results and Discussion}

Cytological analyses of meiocytes in prophase I revealed 12 chromosomes in bivalent association, for a total of 24 chromosomes in diakinesis $(2 n=24$, Figure1a).

Cytoplasmic connections joining pollen mother cells (PMC) were observed in four of the six analyzed individuals (HUEM 16283, HUEM 16417, HUEM 21970 and HUEM 23888) (Table 1). The connections disappeared in early meiosis while still in prophase I, and only HUEM 21970 displayed cytoplasmic connections during metaphase I (Figure 1b).
Gates (1908), analyzing an Oenothera species, described the cytoplasmic connections as thin, delicate, threadlike connections, resembling those that connect adjacent pollen mother cells. Heslop-Harrison (1966) suggested that cytoplasmic channels are formed in early prophase I connecting pre-meiotic cells, which plays a crucial role in cellular synchronization; these channels are disrupted resulting in complete separation of meiocytes during meiosis.

Wang et al. (2002), while working with Lilium davidii, observed that cytoplasmic channel formation occurred in the beginning of prophase I in the zygotene phase, and disappeared at the end of pachytene due to callose deposition.

FIGURE 1: Meiotic Abnormalities in Cordia ecalyculata. a) Diakinesis with 12 bivalent chromosomes; b) metaphase I with cytoplasmic channel joining two meiocytes (arrow); c) metaphase I with non-congressed chromosome (arrow); d) metaphase I with precociously migrating chromosomes (arrow); e) telophase I with micronucleus (arrow); f) metaphase II with both irregular spindle and non-congressed chromosome; g) anaphase II with both irregular spindle and lagging chromosomes; h) metaphase II with T-shaped irregular spindle; i) metaphase II with V-shaped irregular spindle; j) telophase II with T-shaped irregular spindle; k) telophase II with V-shaped irregular spindle; 1) Late telophase II with V-shaped irregular spindle, showing nucleus proximity; m) telophase II with refunded nucleus; n) normal telophase II; o) triad; p) normal tetrad; q) tetrad with unbalanced microspores; r) unbalanced final product (arrow) and 2n (arrow head). Bar: $10 \mu \mathrm{m}$.

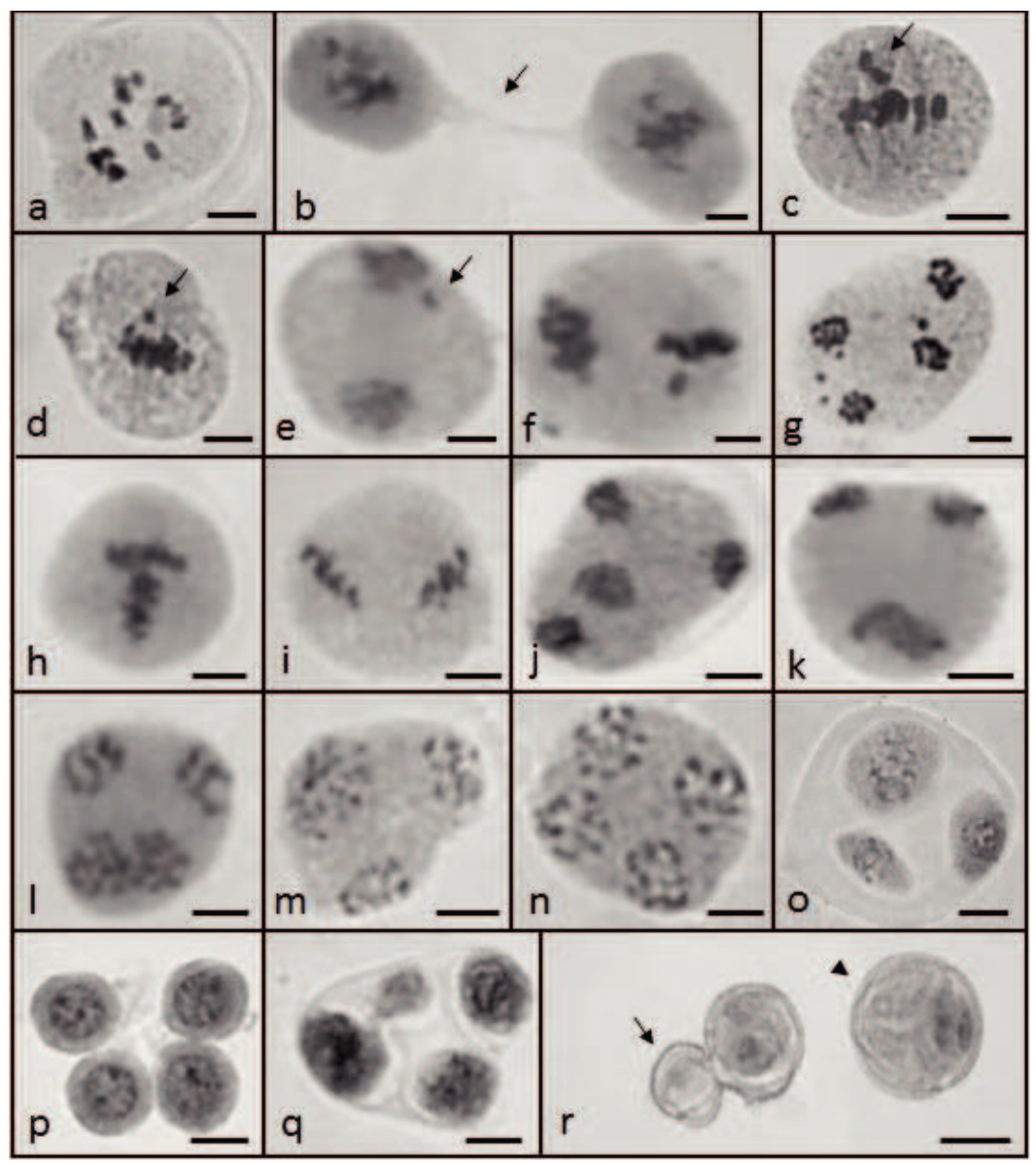


Irregularities related to the chromosomal segregation process were observed at low frequency in C. ecalyculata. In five of the six analyzed individuals, we observed the presence of non-congressed chromosomes during metaphase I (Figure 1c, Table 1).
Non-congressing chromosomes, also called disoriented chromosomes, may arise from spindle fiber connection errors in the chromosome kinetochore (ADAMOWSKI et al., 2000).

TABLE 1: Aspects of microsporogenesis in C. ecalyculata Vell.

\begin{tabular}{lcccccc}
\hline Phase & \multicolumn{5}{c}{ Individuals analyzed } \\
Abnormalities & HUEM 16283 & HUEM 16417 & HUEM 21970 & HUEM 23888 & HUEM 23897 & HUEM 25385 \\
\hline METAPHASE I & $\mathbf{1 0 4}$ & $\mathbf{1 3 6}$ & $\mathbf{1 0 7}$ & $\mathbf{1 4 0}$ & $\mathbf{1 4 0}$ & $\mathbf{1 5 8}$ \\
Cytoplasmic channels & - & - & $02(1,87 \%)$ & - & - & - \\
Precocious migration & $04(3,85 \%)$ & $04(2,94 \%)$ & $02(1,87 \%)$ & $06(4,29 \%)$ & $06(4,28 \%)$ & $07(4,43 \%)$ \\
Non-congression & - & $12(8,82 \%)$ & $14(13,08 \%)$ & $01(0,71 \%)$ & $04(2,86 \%)$ & $04(2,53 \%)$ \\
ANAPHASE I & $\mathbf{9 7}$ & $\mathbf{1 1 2}$ & $\mathbf{8 7}$ & $\mathbf{6 1}$ & $\mathbf{1 2 8}$ & $\mathbf{8 9}$ \\
Lagging & $04(4,12 \%)$ & $08(7,14 \%)$ & $03(3,45 \%)$ & $01(1,64 \%)$ & $02(1,56 \%)$ & - \\
TELOPHASE I & $\mathbf{1 0 6}$ & $\mathbf{1 6 0}$ & $\mathbf{1 5 2}$ & $\mathbf{1 7 2}$ & $\mathbf{1 5 7}$ & $\mathbf{1 3 7}$ \\
Micronuclei & $02(1,89 \%)$ & $11(6,87 \%)$ & $06(3,95 \%)$ & - & $02(1,27 \%)$ & $03(2,19 \%)$ \\
PROPHASE II & $\mathbf{1 5 2}$ & $\mathbf{1 6 4}$ & $\mathbf{1 8 2}$ & $\mathbf{1 6 2}$ & $\mathbf{1 1 2}$ & $\mathbf{1 7 5}$ \\
Micronuclei & - & $08(4,88 \%)$ & $04(2,20 \%)$ & $02(1,23 \%)$ & - & - \\
METAPHASE II & $\mathbf{1 6 6}$ & $\mathbf{1 7 4}$ & $\mathbf{1 1 6}$ & $\mathbf{1 6 6}$ & $\mathbf{1 2 1}$ & $\mathbf{1 6 6}$ \\
Non-congression & - & $05(2,87 \%)$ & $09(7,76 \%)$ & $11(6,63 \%)$ & - & - \\
Precocious migration & $14(8,43 \%)$ & - & - & - & - & - \\
T-shaped spindle & $08(4,82 \%)$ & $05(2,87 \%)$ & $19(16,38 \%)$ & $11(6,63 \%)$ & - & $05(3,01 \%)$ \\
V-shaped spindle & $16(9,64 \%)$ & $21(12,07 \%)$ & $17(14,66 \%)$ & $09(5,42 \%)$ & - & $08(4,82 \%)$ \\
ANAPHASE II & $\mathbf{1 2 8}$ & $\mathbf{1 4 4}$ & $\mathbf{1 3 3}$ & $\mathbf{1 0 4}$ & $\mathbf{7 2}$ & $\mathbf{9 3}$ \\
Lagging & $04(3,12 \%)$ & - & $03(2,25 \%)$ & $04(3,85 \%)$ & - & - \\
T-shaped spindle & $06(4,69 \%)$ & $04(2,78 \%)$ & $09(6,77 \%)$ & $07(6,73 \%)$ & - & $02(2,15 \%)$ \\
V-shaped spindle & $11(8,59 \%)$ & $16(11,11 \%)$ & $21(15,79 \%)$ & $08(7,69 \%)$ & - & $03(3,22 \%)$ \\
TELOPHASE II & $\mathbf{1 5 3}$ & $\mathbf{1 7 4}$ & $\mathbf{1 2 1}$ & $\mathbf{1 6 9}$ & $\mathbf{1 4 4}$ & $\mathbf{1 7 6}$ \\
Micronuclei & $03(1,96 \%)$ & - & $02(1,65 \%)$ & $02(1,18 \%)$ & - & $02(1,14 \%)$ \\
T-shaped spindle & - & $15(8,62 \%)$ & $09(7,44 \%)$ & $08(4,73 \%)$ & - & $03(1,70 \%)$ \\
V-shaped spindle & $03(1,96 \%)$ & $05(2,87 \%)$ & $14(11,57 \%)$ & $09(5,33 \%)$ & - & $05(2,84 \%)$ \\
TETRAD & $\mathbf{1 8 6}$ & $\mathbf{1 7 1}$ & $\mathbf{4 0 3}$ & $\mathbf{2 3 4}$ & $\mathbf{1 8 2}$ & $\mathbf{1 8 8}$ \\
Triad formation & - & - & $06(1,49 \%)$ & $04(1,71 \%)$ & - & $04(2,12 \%)$ \\
\hline Total & $\mathbf{1 0 9 2}$ & $\mathbf{1 2 3 5}$ & $\mathbf{1 3 0 1}$ & $\mathbf{1 2 0 8}$ & $\mathbf{1 0 5 6}$ & $\mathbf{1 1 8 2}$ \\
\hline & & & & & &
\end{tabular}

Precocious migration of chromosomes in metaphase I was observed in all six individuals analyzed (Table 1), in which some homologous chromosomes became separated and migrated to opposite poles early (Figure 1d). According to Kiihl et al. (2010), early migration to the poles may occur due to absence or early terminalization of chiasmata. Chiasmata are formed after crossing-over during prophase I, having the function of keeping the homologous chromosomes together until the onset of anaphase I (ALBERTS et al., 2010). Pagliarini (2000) suggested that precocious migration of the chromosomes to the poles may be due to the presence of asynaptic (as) and desynaptic (dy) genes. Thus, during prophase I synapse absence results in lack of chiasma formation.

Until early anaphase I, the homologous chromosomes are held together by chiasmata, which are formed in prophase I. At this stage the disruption of centromeres and the shortening of the spindle fibers causes each chromosome to be pulled to opposite poles. Chromosomes that remain delayed (in relation to the majority) in migrating to the poles during segregation are 
called 'lagging' chromosomes. Pagliarini and Pozzobon (2005) suggest that the cause of lagging chromosomes in anaphase I may be late terminalization of chiasmata.

Early-migrating chromosomes in metaphase I, and laggards in anaphase I cannot be incorporated into telophasic nuclei to form micronuclei (Figure 1e). The micronucleus constitutes a small nuclear mass, and may have one or more chromosomes, delimited by the membrane and separate from the main core (FENECH, 1997). Micronuclei were observed in both telophase I and prophase II.

Following meiosis II, disoriented chromosomes arising in metaphase II, and lagging chromosomes in anaphase II were visualized (Figure 1f, g) (Table 1). The irregular segregation of chromosomes in meiosis I and II can lead to the formation of micronuclei at the end of meiosis, and after cytokinesis, may either remain in microspore tetrads or may be eliminated in the form of microcytes for an additional cytokinesis. In this case, the formed tetrads will be genetically unbalanced, and the resulting unbalanced microspores will be unviable.

Irregularities related to the chromosomal segregation process, such as disoriented chromosomes, precociously migrating chromosomes, laggard chromosomes and micronuclei formation, have been reported in several different plant species, including: Psychotria carthagenensis (CORREAA; FORNI-MARTINS, 2004), Brachiaria brizantha (MENDES-VIEIRA et al., 2006.), Meconopsis aculeata (SINGHAL; KUMAR, 2008), Brachiaria bovonei (RISSO-PASCOTTO et al., 2009), Passiflora serrato-digitata (KIIHL et al., 2011), Meliaceae species (GROSSI et al., 2011), Alchornea triplinervia (GODOY et al., 2012), and Psychotria myriantha (ALONSO-PEREIRA et al., 2013).

Another irregularity observed was the occurrence of irregular spindles in meiosis II. Five of the six individuals analyzed showed changes in the organization of the spindles, observed from metaphase II to telophase II. The individual HUEM 21970 showed the highest frequency of affected cells (Table 1). When irregular organization occurred, the most common conformations observed were a T-shaped transverse spindle formation (Figure 1h, J), followed by the V-shaped formation of the convergent zone (Figure 1i, k). According to Shamina et al. (2000), the conformation of the spindles is under genetic control, and a mutation in the gene can change their orientation. During polymerization, rather than arrange themselves in a parallel form, the zones are organized transversely or convergently, with a T-shaped or V-shaped configuration, respectively.

When oriented convergently, the resulting V-shaped spindle can lead to convergence of telophasic nuclei which may then become fused, generating a $2 n$ nucleus, (i.e., a restitution nucleus) that forms a triad instead of tetrad after cytokinesis (ENDOW, 1999). HUEM 16283, HUEM 16417, HUEM 21970, HUEM 23888 and HUEM 25385 all presented V-shaped telophase II (Figure 11, m). Triads (Figure 10) were observed only HUEM 21970, HUEM 23888 and HUEM 25385, often ranging from $1.49 \%$ to $2.12 \%$ (Table 1). A triad consists of two microspores, one $\mathrm{n}$ and one $2 \mathrm{n}$, leading to formation of $2 \mathrm{n}$ gametes. The formation of $2 \mathrm{n}$ microspores (Figure 1r) and $2 \mathrm{n}$ pollen grains was observed in $0.87 \%$ and $1.81 \%$ of post-meiotic products analyzed, respectively (Table 2 ).

TABLE 2: Final products of meiosis in C. ecalyculata Vell.

\begin{tabular}{lcccccc}
\hline \multirow{2}{*}{ Phase } & \multicolumn{7}{c}{ Individuals analyzed } \\
\cline { 2 - 7 } Abnormalities & HUEM & HUEM & HUEM & HUEM & HUEM & HUEM \\
& 16283 & 16417 & 21970 & 23888 & 23897 & 25385 \\
\hline MICROSPORE & $\mathbf{3 7 8}$ & $\mathbf{3 1 7}$ & $\mathbf{4 4 0}$ & $\mathbf{3 1 8}$ & $\mathbf{4 1 0}$ & $\mathbf{3 2 0}$ \\
Unbalanced & $08(2,11 \%)$ & - & - & - & - & - \\
2n & - & $03(0,95 \%)$ & $02(0,45 \%)$ & $09(2,83 \%)$ & - & $05(1,56 \%)$ \\
POLLEN GRAIN & $\mathbf{3 5 6}$ & $\mathbf{3 2 0}$ & $\mathbf{4 5 7}$ & $\mathbf{3 9 3}$ & $\mathbf{3 9 0}$ & $\mathbf{2 3 3}$ \\
Unbalanced & - & $03(0,93 \%)$ & $05(1.09 \%)$ & $08(2,04 \%)$ & - & $02(0,85 \%)$ \\
2n & - & $05(1,56 \%)$ & $04(0.87 \%)$ & $10(2,54 \%)$ & & $02(0,85 \%)$ \\
\hline
\end{tabular}


Similar studies (e.g., SOUZA et al., 1999, 2003; PASCOTTO-RISSO et al., 2005; RICCI et al., 2007; SHEIDAI et al., 2009; KIIHL et al., 2010; SOUZAKANESHIMA et al., 2010; GROSSI et al., 2011; GODOY et al., 2012) correlate telophasic nucleic fusion and subsequent formation of $2 \mathrm{n}$ microspores with T-shaped convergent spindle formation.

The observed irregularities in this study did not compromise the fertility of the species in question, as viability of pollen grains ranged from $95.42 \%$ to $100 \%$. Therefore, the process of microsporogenesis in $C$. ecalyculata seems well adapted, and may be included in future breeding programs involving the species.

\section{References}

ADAMOWSKI, E. V.; PAGLIARINI, M. S.; BATISTA, L. A. R. Chromosome number and microsporogenesis in Paspalum maritimum (Caespitosa Group; Gramineae). Brazilian Archives of Biology and Technology, Curitiba, v. 43, n. 3, p. 1-6, 2000.

ALBERTS, B.; JOHNSON, A.; LEWIS, J.; RAFF, M.; ROBERTS, K.; WALTER, P. Biologia molecular da célula. 5 ed. Porto Alegre: Artmed, 2010. 1396 p.

ALONSO-PEREIRA, A. R.; GODOY, S. M.; RISSO-PASCOTTO, C. Irregular cytokinesis during microsporogenesis of Psychotria myriantha Mull. Arg. Scientific Journal of Biological Sciences, New York, v. 2, n. 11, p. 227-231, 2013.

AUlER, N. M. F.; BATTISTIN, A.; REIS, M. S. Número de cromossomos, microsporogênese e viabilidade do pólen em populações de carqueja Baccharis trimera (Less) $D C$. Rio Grande do Sul e Santa Catarina. Revista Brasileira de Plantas Medicinais, Botucatu, v. 8, p. 55-63, 2006.

CAETANO-PEREIRA, C. M.; PAGLIARINI, M. S.; BRASIL, E. M. Cell fusion and chromatin degeneration in a inbred line of maize. Genetics and Molecular Biology, Ribeirão Preto, v. 22, n. 1, p. 69-72, 1999.

CORRÊA, A. M.; FORNI-MARTINS, E. R. Chromosomal studies of species of Rubiaceae (A. L. de Jussieu) from the Brazilian cerrado. Caryologia, Firenze, v. 57, n. 3, p. 250-258, 2004.

CRUZ, G. L. Dicionário das plantas úteis do Brasil. 5 ed. Rio de Janeiro: Bertrand, 1995. 599 p.

ENDOW, S. A. Microtubule motors in spindle and chromosome motility. European Journal of Biochemistry, Dublin, v. 262, p. 12-18, 1999.

FENECH, M. The adventages and disadvantages of the cytokinesisblock micronucleus method. Mutation Research, Amsterdam, v. 392, p. 11-18, 1997.

FIDALGO, O.; BONONI, V. L. R. Técnicas de coleta, preservação e herborização de material botânico. São Paulo: Instituto de Botânica/Secretária do Meio Ambiente, 1989. p. 62.

GATES, R. R. A study of reduction in Oenothera rubrinervis. Annals of Botany, Oxford, v. 46, p. 1-34, 1908.
GODOY, S. M.; PEREIRA, A. R. A.; ROMAGNOLO, M. B.; RISSO-PASCOTTO, C. Meiotic behavior during microsporogenesis of Alchornea triplinervia (Sprengel) Müller Argoviensis. Ciência Rural, Santa Maria, v. 42, n. 6, p. 1027-1032, 2012.

GROSSI, J. A.; GODOY, S. M.; MACEDO, C. R.; PAULA, G. B. N.; ROMAGNOLO, M. B.; RISSO-PASCOTTO C. Comportamento meiótico durante a microsporogênese em espécies da família Meliaceae. Arquivos de Ciências Veterinárias e Zoologia da UNIPAR, Umuarama, v. 14, n. 1, p. 51-56, 2011.

HESLOP-HARRISON, J. Cytoplasmic connexions between angiosperm meiocytes. Annals of Botany, Oxford, v. 30, p. 221 230, 1966.

KIIHL, P. R. P.; BARRAGAN, M. F.; SANTOS, S. P.; GODOY, S. M.; ALONSO-PEREIRA, A. R.; STENZEL, N. M. C.; RISSO-PASCOTTO, C. Abnormal behavior of spindle during microsporogenesis of Passiflora (Passifloraceae). Arquivos de Ciências da Saúde da UNIPAR, Umuarama, v. 14, n. 3, p. $237-$ 243,2010

KIIHL, P. R. P.; PEREIRA, A. R. A.; GODOY, S. M. DE; STENZEL, N. M. C. RISSO-PASCOTTO, C. Chromosome stickiness during meiotic behavior analysis of Passiflora serratodigitata L. (PASSIFLORACEAE). Ciência Rural, Santa Maria, v. 41, n. 6, p. 1018-1023, 2011.

LORENZI, H. Árvores brasileiras: manual de identificação e cultivo de plantas arbóreas do Brasil. 4. ed. Nova Odessa: Instituto Plantarum, 2002. 368 p.

LORENZI, H.; MATOS, F. J. A. Plantas medicinais no Brasil: nativas e exóticas cultivadas. 2. ed. Nova Odessa: Instituto Plantarum, 2008. $541 \mathrm{p}$

MENDES-VIEIRA, D.; MENDES-BONATO,A. B.; PAGLIARINI, M. S.; VALLE, C. B. do Abnormal meiotic behavior in Brachiaria brizantha (Poaceae) leading to microspore degeneration. Caryologia, Firenze, v. 58, p. 396-402, 2006

MONDIN, M.; NETO, A. D. Citogenética vegetal enfatizando a família Orchidaceae. Orchidstudium, Poços de Caldas, v. 4, p. 24 54, 2006

PAGLIARINI, M. S. Meiotic behavior of economically important plant species: the relationship between fertility and male sterility. Genetics and Molecular Biology, Ribeirão Preto, v. 23, n. 4, p. 997-1002, 2000.

PAGLIARINI, M. S.; POZZOBON, M, T. Meiose em vegetais: um enfoque para caracterização de germoplasma. II Curso de citogenética aplicada a recursos gaméticos vegetais. 2005. Disponível em: <http://www.cenargen.embrapa.br/clp/publicacoes/ doc/doc154.pdf>. Acesso em: 22 jun. 2013.

RICCI, G. C. L.; SILVA, N.; PAGLIARINI, M. S.; SCAPIM, C. A. Microsporogenesis in inbred line of popcorn (Zea mays L.). Genetics and Molecular Biology, Ribeirão Preto, v. 6, n. 4, p. 1013-1018, 2007.

RISSO-PASCOTTO, C.; PAGLIARINI, M. S.; VALLE, C. B Mutiple spindles and cellularization during microsporogenesis in an artificially induced tetraploid accession of Brachiaria ruziziensis (Gramineae). Plant Cell Reports, New York, v. 23, n. 8, p. 522$527,2005$.

RISSO-PASCOTTO, C.; PAGLIARINI, M. S.; VALLE, C. B. Microsporogenesis in Brachiaria bovonei (Chiov.) Robynsand $B$. 
subulifolia (Mez) Clayton (Poaceae). Scientia Agricola, Piracicaba, v. 66, n. 5, p. 573-711, 2009.

SHAMINA, N.; DORAGOVA, N.; TRUNOVA, S. Radial spindle and the phenotype of the maize meiotic mutant, dv. Cell Biology International, Malden, v. 24, p. 729-736, 2000.

SHEIDAI, M.; AZANEI, N.; ATTAR, F. New chromosome number and unreduced pollen formation in Achillea species (Asteraceae). Acta Biologica Szegediensis, Szeged, v. 53, n. 1, p. 39-43, 2009.

SINGHAL, V. K.; KUMAR, P. Impact of cytomixis on meiosis, pollen viability and pollen size in wild populations of Himalayan poppy (Meconopsis aculeata Royle). Journal of Biosciences, Tübingen, v. 33, n. 3, p. 371-380, 2008.

SOUZA, A. M.; PAGLIARINI, M. S.; CARRARO, I. M. Abnormal spindles in second meiosis in canola (Brassica napus and Brassica campestris). Brazilian Archives of Biology and Technology, Curitiba, v. 42, p. 47-52, 1999.
SOUZA, M. M.; PEREIRA, T. N. S.; VIANA, A. P.; PEREIRA, M. G.; BERNACCI, L. C.; SUDRÉ, C. P.; SILVA, L. C. Meiotic irregularities and pollen viability in Passiflora edmundoi Sacco (Passifloraceae). Caryologia, Firenze, v. 56, n. 2, p. 161-169, 2003.

SOUZA, V. C.; LORENZI, H. Botânica sistemática: guia ilustrado para identificação das famílias de Angiospermas da flora brasileira. Nova Odessa: Instituto Plantarum, 2005. 640 p.

SOUZA-KANESHIMA, A. M.; SIMIONI, C.; FELISMINO, M. F.; MENDES-BONATO, A. B.; RISSO-PASCOTTO, C.; PESSIM, C.; PAGLIARINI, M. S.; VALLE, C.B. Meiotic behaviour in the first interspecific hybrids between Brachiaria brizantha and Brachiaria decumbens. Plant Breeding, Westport, v. 129, n. 2, p. 186-191, 2010.

WANG, X. Y.; XIU, X. W.; GUO, G. Q.; PAN, Y. F.; ZHENG, G. C. Ultrastructural characterization of the cytoplasmic channel formation between pollen mother cells of David lily. Caryologia, Firenze, v. 55, p. 161-169, 2002. 